Pemanfaatan Minyak Biji Labu.........Rohani, Shibghatun, Romdhonah, Lily.

\title{
PEMANFAATAN MINYAK BIJI LABU KUNING (Cucurbita moschata Durch) MENJADI SEDIAAN NANOEMULSI TOPIKAL SEBAGAI AGEN PENGEMBANGAN COSMETICAL ANTI AGING
}

\author{
Rohani Panjaitan, Shibghatun Ni'mah, Romdhonah, Lily Annisa \\ Jurusan Farmasi, Fakultas Matematika dan Ilmu Pengetahuan Alam, \\ Universitas Islam Indonesia
}

\section{RINGKASAN}

Kulit merupakan bagian tubuh paling luar yang berfungsi sebagai pelindung dan merupakan salah satu jalur ekskresi tubuh. Oleh karena itu, kulit sangat rentan mengalami paparan agen fisik dan kimia yang dapat menyebabkan kerusakan pada sel-sel kulit. Kerusakan tersebut dapat menyebabkan kulit menjadi kusam dan dapat mempercepat penuaan serta berisiko terkena kanker kulit.

Indonesia merupakan negara agraris yang sebagian besar perekonomiannya mengandalkan sektor pertanian. Ragam tanaman yang diproduksinya pun banyak mulai dari tanaman palawija, sayur-sayuran hingga buah-buahan, dan di antara beragam tanaman tersebut selain berfungsi untuk memenuhi bahan pangan juga dapat bermanfaat dalam pengembangan di bidang kesehatan.

Aging merupakan suatu proses penuaan yang ditandai dengan penurunan energi seluler yang menurunkankemampuan sel untuk memperbaiki diri. Agen kimia seperti polutan, asap rokok, sinar matahari berlebih yang mengandung radikal bebas dari peroksida yang mengikat oksigen adalah faktor lingkungan yang dapat mempercepat penuaan atau yang dikenal dengan penuaan dini.

Labu kuning atau Cucurbita moschata merupakan tanaman yang banyak dimanfaatkan sebagai bahan pangan. Pemanfaatan bijinya di Indonesia masih terbatas pada produksi kuaci biji labu sedangakan biji labu kuning ternyata memiliki beberapa senyawa yang sangat berpotensi sebagai antiaging. Diantaranya adalah asam lemak utama, vitamin E, karotenoid, asam amino, dan inhibitor tripsin. Senyawa-senyawa tersebut bermanfaat untuk menghambat peroksida menjadi radikal bebas, sebab radikal bebas tersebut dapat merusak 
membran sel yang dapat berakibat pada penyakit degeneratif dan kanker kulit.

Penelitian ini dimaksudkan memanfaatkan minyak biji labu untuk dibuat dalam sediaan nanoemulsi dan mengetahui stabilitas sediaan nanoemulsi minyak biji labu tersebut. Penelitian ini akan dilakukan di laboratorium Fakultas Matematika dan IImu Pengetahuan Alam Universitas Islam Indonesia selama 3-4 bulan dengan evaluasi stabilitas fisik dari sediaan.

\section{BAB 1. PENDAHULUAN}

\subsection{Latar Belakang}

Kulit merupakan organ yang menutupi permukaan tubuh dan membentuk perbatasan antara tubuh dengan lingkungan (Wilkinson \& Moore, 1982). Oleh karena kulit berada pada permukaan tubuh paling luar sehingga kulit paling sering terpapar berbagai agen fisik maupun kimia yang menimbulkan kerusakan pada jaringan kulit. Aging merupakan suatu proses penuaan yang ditandai dengan ditandai penurunan energi seluler yang menurunkankemampuan sel untuk memperbaiki diri. Agen kimia seperti polutan, asap rokok, sinar matahari berlebih yang mengandung radikal bebas dari peroksida yang mengikat oksigen adalah faktor lingkungan yang dapat mempercepat penuaan atau yang dikenal dengan penuaan dini.

Indonesia kaya akan tanaman budidaya yang dapat dimanfaatkan dalam pengembangan ilmu pengetahuan. Salah satu budidaya yang banyak ditanam di Indonesia adalah buah labu kuning. Menurut sudarto (2000) buah labu kuning adalah jenis tanaman yang mudah tumbuh dan tidak sulitbaik dari segi pembibitannya dan perawatannya, hasilnya pun cukup memberikan nilai ekonomis untuk masyarakat.

Objek yang akan diteliti adalah minyak biji labu kuning.Biji labu kuning memiliki kandungan berkhasiat seperti asam amino, Zn (seng), Mg (magnesium), asam lemak utama, vitamin E (tokoferol), karetenoid, sterol, kriptoxantin, sesquiterpenoid monosiklik dan inhibitor tripsin yang dapat menghambat peroksida yang berubah menjadi radikal bebasdan mampu mengoksidasi asam lemak tidak jenuh dalam membran sel sehingga merusak membran tersebutdan menjadi agen anti aging. Oleh karena itulah banyak pakar mengatakan biji labu ini mempunyai potensi untuk mencegah terjadinya penuaan dini. Minyak biji labu kuning akan dikembangkan dalam bentuk sediaan nanoemulsi karena diharapkan diperoleh sediaan yang lebih stabil karena dengan ukuran globul yang sangat kecil 
Pemanfaatan Minyak Biji Labu.........Rohani, Shibghatun, Romdhonah, Lily.

dapat mencegah terjadinya creaming, sedimentasi, koalesens, dan membuat nanoemulsi semakin unik, mendekati stabilitas termodinamik dan lebih menarik dalam hal penampilan fisik karena penampilannya yang jernih dan transparan tidak seperti emulsi biasa( Tardos, 2005; Solans, 2003). Selain itu memiliki efektifitas yang tinggi dalam menembus stratum corneum pada kulit juga dapat mengurangi penyebab penuaan dalam tubuh atau lebih dikenal sebagai anti aging (Swarbrick, 2007). Sediaan nanoemulsi topikal yang diperoleh dapat dipasarkan menjadi produk yang bermanfaat bagi masyarakat untuk mencegah penuaan dini pada kulit khususnya kaum wanita.

Pada penelitian sebelumnya di Indonesia oleh Raharjo dkk (2011), minyak biji labu kuning (Cucurbita moschata D.) hanya sebatas dianalisisnya kandungan asam lemak dari minyak biji labu, selain itu penelitian Vermaak I., et al memanfaatkan minyak biji labu hanya kandungan asam lemak sebagai kosmetik. Oleh karena itu peneliti mengambil senyawa vitamin $\mathrm{E}$ dalam minyak biji labu kuning dalam pengembangan sediaan kosmetik nanoemulsi.

\subsection{Rumusan Masalah}

a. Apakah minyak biji labu kuning dapat dimanfaatkan menjadi sediaan nanoemulsi topikal?
b. Bagaimana stabilitas nano- emulsi topikal yang digunakan untuk anti aging?

\subsection{Tujuan Penelitian}
a. Pemanfaatan minyak biji labu kuning (Curcubita) menjadi se- diaan nanoemulsi topikal
b. Pengembangan minyak biji labu kuning (Curcubita) dalam sediaan nanoemulsi topikal se- bagai kosmetik anti aging.

\subsection{Urgensi penelitian}

Pada penelitian ini pengembangan sediaan nanoemulsi yang masih jarang diaplikasikan dalam ilmu kefarmasiaan dengan bahan dasar yang juga masih kurang dimanfaatkan oleh para ilmuan dan masyarakat. Bahan dasar tersebut yaitu biji labu kuning, dikalangan masyarakat hanya dibuang setelah mendapatkan daging buah labu kuning (curcubita). Maka dari itu dengan mengolah biji labu kuning menjadi minyak yang mengandung senyawa-senyawa sebagai anti aging dalam bentuk sediaan nanoemulasi topikal. Pengembangan ini juga dapat membantu masalah penuaan para wanita khususnya, kulit kusam akibat polusi udara atau asap rokok dan lain sebagainya.

\subsection{Konstribusi Penelitian}

Memberikan informasi pengembangan minyak biji labu 
kuning menjadi nanoemulsi topikal sebagai anti aging dalam memenuhi kebutuhan masyarakat dengan harga yang terjangkau, karena labu kuning yang mudah didapat dan murah dipasaran. Sehingga secara tidak langsung dapat pula membantu industri kosmetik dalam mengembangkan formula kosmetik.

\subsection{Luaran Penelitian}

Diharapkan hasil sediaan nanoemulsi topikal dari minyak biji labu kuning yang efektif dan efisien ini dapat menghasilkan pendapatan ekonomi, tentunya juga diiringidengan peningkatan taraf kesehatan masyarakat dari segi pencegahan dari penuaan dini. Hasil formulasi ini, peniliti dapat bekerja sama dengan industri kosmetik untuk memunculkan suatu produk baru dimasyarakat yang bermanfaat

\subsection{Manfaat Penelitian}

1. Terbentuknya produk baru anti aging dari minyak biji labu kuning dalam pengembangan ilmu pengetahuan dibidang kefarmasian

2. Terpenuhinya kebutuhan masyarakat dalam pencegahan penuaan diusia dini dan meminimalisir kerutan di wajah yang menjadi masalah bagi kaum wanita.
3. Meningkatkan taraf kesehatan masyarakat melalui pengembangan ilmu kefarmasian yang membantu tujuan pemerintah dalam bidang kesehatan.

\section{BAB 2. TINJAUAN PUSTAKA}

\subsection{Labu Kuning}

\subsubsection{Klasifikasi Labu Kuning}

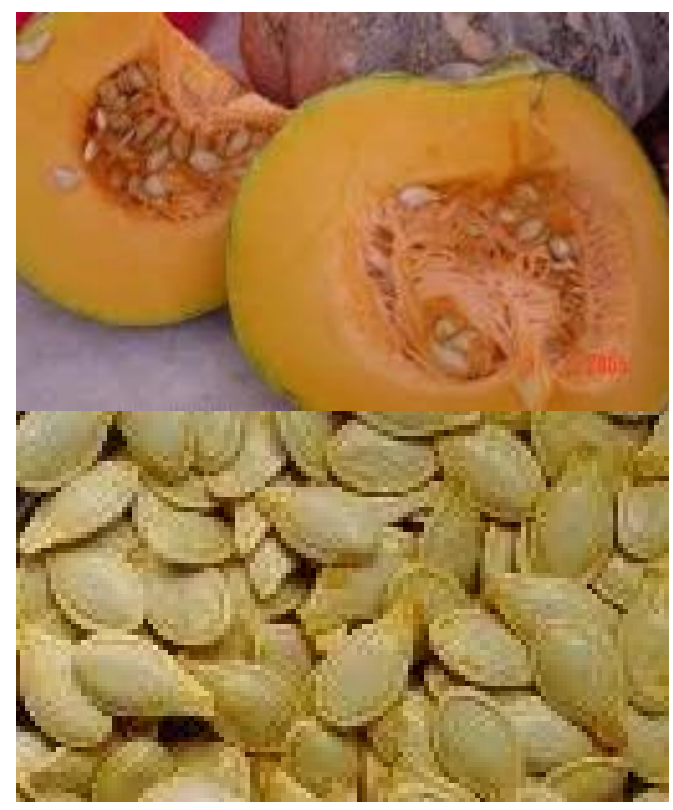

(gambar 1. Buah Labu Kuning) (gambar 2. Biji Labu Kuning)

Kingdom : Plantae

Divisi : Spermatophyta

Sub divisi : Angiospermae

Kelas : Dicotyledonae

Ordo : Cucurbitales

Familia : Cucurbitaceae

Genus : Cucurbita

Spesies : Cucurbita moschata Durch

(Hutapea, J.R, 1994) 


\subsubsection{Morfologi}

Labu kuning merupakan tanaman yang berasal dari Benua Amerika terutama di Negara Peru dan Meksiko. Terdapat lima spesies labu kuning yang umum dikenal, yaitu Cucurbita maxima Duchenes, Cucurbita ficifolia Bouche, Cucurbita mixta, Cucurbita moschata Duchenes dan Cucurbita pipo L (Brotodjojo, 2010). Buah labu kuning berbentuk bulat pipih, lonjong, atau panjang dengan banyak alur (15-30 alur). Ukuran pertumbuhannya mencapai 350 gram per hari. Buahnya besar dan warnanya hijau apabila masih muda, sedangkan yang lebih tua berwarna kuning orange sampai kuning kecokelatan. Daging buah tebalnya sekitar $3 \mathrm{~cm}$ dan rasanya agak manis. Bobot buah ratarata $3-5 \mathrm{~kg}$ bahkan sampai $15 \mathrm{~kg}$. Bunganya besar dan berwarna kuning dengan mahkota bunga berbentuk lonceng, ujungnya melebar, bergigi tidak beratur, dan berambut. Biji berbentuk oval pipih, panjangnya mencapai $2 \mathrm{~cm}$, lebar mencapai $5 \mathrm{~mm}$, berwarna kekuningan atau abu-abu.

\subsubsection{Kandungan kimia biji labu kuning}

Biji waluh mengandung zatzat yang berkhasiat seperti asam amino, $\mathrm{Zn}$ (seng), $\mathrm{Mg}$ (magnesium), Asam lemak utama (linoleat, oleat, palmitat, dan stearat), vitamin $\mathrm{E}$ (tokoferol), karetenoid, sterol, kriptoxantin, sesquiterpenoid monosiklik dan inhibitor tripsin (Hargono, 1999).

\subsubsection{Kegunaan}

Dalam pengobatan tradisional di Amerika Utara dan Meksiko, biji labu telah digunakan sebagai agen antelmintik dan pengobatan suportif dalam gangguan fungsional kandung kemih.Biji labu juga digunakan sebagai anti- inflamasi dan kardioprotektif. Kegunaan labu kuning di Indonesia masih sebatas daging buah yang dapat diolah menjadi panganan seperti kue basah, kolak dan sayur berkuah.Sedangkan untuk pemanfaatan biji waluh kurang maksimal, hanya sebatas kuaci waluh (Hargono, 1999).

\subsubsection{Mekanisme Kerja Minyak} Biji Labu Kuning sebagai anti aging

Minyak biji labu mengandung senyawa seperti, asam linoleat, protein, $\mathrm{Zn}$, dan antioksidan (karotenoid, tokoferol). Senyawa-senyawa ini berperan dalam memproteksi kulit dari proses penuaan (aging) dengan mekanisme yang berbeda. Kandungan senyawa minyak biji labu ini dapat memperlambat proses penuaan dan dapat melindungi sel dari oksidasi radikal bebas serta bereaksi dengan lipid yang 
dihasilkan dalam reaksi berantai peroksidasi lipid dengan cara memberikan elektronnya kepada molekul radikal bebas tanpa terganggu sama sekali fungsinya (Mi Young, kim., et al, 2012). Selain itu, dapat juga menurun ROS (reactive oxygen species) dengan penghambatan oksidase NADPH dan dapat menjaga kelembapan kulit serta menyediakan energi bagi yang mendukung proses regenerasi jaringan ikat sel dengan merangsang produksi kolagen dan elastin (Williams, Abumrad\& Barbul, 2002).

\subsection{Nanoemulsi}

Nanoemulsi adalah sistem transparan atau bening dengan ukuran globul seragam dan sangat kecil (biasannya dalam kisaran 2-500 nm). Nanoemulsi stabil secara kinetik. Namun, karena memiliki stabilitas jangka panjang (tanpa flokulasi atau koalense), membuat nanoemulsi menjadi unik dan terkadang disebut "mendekati stabilitas termodinamik" (Tadros, 2005; Solans, 2003; Fast \& Mecozzi, 2009).

Nanoemulsi terdiri atas globulglobul berukuran nano dari cairan yang terdispersi dalam cairan lainnya. Nanoemulsi merupakan sistem metastabil dimana stukturnya bergantung dari proses pembuatannya, yaitu emulsifikasi spontan atau menggunakan lata dengan kecepatan tinggi. Nanoemulsi terbentuk sebagai cairan seperti air, losion, atau gel (korting(a) \& korting (b), 2010).

Nanoemulsi memiliki keuntungan sebagai berikut (Tadros, 2005).

1. Ukuran tetesan sangat kecil menyebabkan penurunan pada gaya gravitasi dan gerak Brown yang mungkin cukup untuk mengatasi gravitasi. Hal ini berarti tidak terjadi creaming atau sedimentasi selama penyimpanan.

2. Ukuran tetesan yang kecil yang kecil mencegah terjadinya flokulasi dan memungkinkan sistem untuk teap tersebar tanpa adanya pemisahan, serta dapat mencegah koalesens.

3. Nanoemulsi cocok untuk penghantaran bahan aktif lewat kulit. Luas permukaan yang besar dari sistem emulsi meningkatkan penetrasi yang cepat dari bahan aktif.

4. Karena ukuran yang kecil, nanoemulsi dapat melewati permukaan kulit yang kasar dan dapat meningkatkan penetrasi obat.

5. Karena sifatnya yang transparan dan fluiditasnya (pada konsentrasi minyak yang sesuai) dapat memberikan estetika yang menarik dan menyenangkan saat digunakan.

6. Ukuran tetesan yang kecil 
Pemanfaatan Minyak Biji Labu.........Rohani, Shibghatun, Romdhonah, Lily.

memudahkan penyebaran dan penetrasi mungkin dapat ditingkatkan karena tegangan permukaan dan tegangan antarmuka rendah

\section{BAB 3. METODE PENELITIAN}

\subsection{Jenis Penelitian}

Penelitian ini bersifat eksperimen yaitu memanfaatkan minyak biji labu kuning sebagai anti aging menjadi produk nanoemulsi topikal.

\subsection{Lokasi penelitian}

Penelitian dilaksanakan di Laboratorium Terpadu Fakultas Matematika dan IImu Pengetahuan Alam, Universitas Islam Indonesia.

\subsection{Subjek Penelitian}

Sampel yang digunakan dalam penelitian ini adalah nanoemulsi topikal sebagai anti penuaan.

\subsection{Objek Penelitian}

Objek penelitian adalah minyak biji labu kuning.

\subsection{Instrumentasi Penelitian}

a. Alat penelitian

Alat yang digunakan dalam penelitian ini antara lain:

Homogenizer, Neraca analitik, Seperangkat alat GC-MS, Seperangkat alat gelas, Seperangkat alat KLT, Seperangkat alat soxhletasi,.

b. Bahan penelitian

Bahan-bahan yang digunakan dalam penelitian ini antara lain: Aquabidestilata, Biji labu, Kertas saring, n-heksana, Sorbitol, Tween 80.

\subsection{Cara Kerja}

\subsubsection{Tahap Pendahuluan}

Perlakuan pendahuluan meliputi pembersihan biji labu dari kotoran, pengeringan dengan udara terbuka, penghalusan dengan menggunakan alat penyerbuk.

\subsubsection{Tahap Ekstraksi Minyak}

Sebanyak 20 gram serbuk biji labu kuning dimasukkan ke dalam kantung yang terbuat dari kertas saring dan kemudian diletakkan ke dalam alat ekstraktor soxhlet. Kemudian diekstraksi menggunakan nheksan sebanyak $80 \mathrm{ml}$. Ekstraksi dilakukan hingga pelarut yang merendam sampel terlihat jernih. Proses ekstraksi ini dilakukan sebanyak 3 kali.

Ekstrak yang berwarna hijau kecoklatan kemudian dipekatkan menggunakan rotary evaporator dengan pengurangan tekanan. Setelah itu dilakukan penguapan di atas waterbath. Ditutup dan disimpan pada tempat yang dingin dalam botol gelap.

\subsubsection{Pembuatan Nanoemulsi}

Dicampur tween 80, sorbitol, dan minyak biji labu kuning dalam gelas beaker.Dibuat dalam tiga formula dengan perbandingna yang berbeda 
yaitu formula I (2:1), formula II (1:1), formula $3(3: 1)$. Ketiga formula dibuat dan masingmasing formula Dilakukan penambahan aquabidestilata dengan metode titrasi sedikit demi sedikit dihomogenkan dengan pengadukan menggunakan magnetic stirrer diatas penangas pada kecepatan 300rpm. Proses penambahan aquabidestilata dihentikan hingga volume mencapai $80 \mathrm{~mL}$. Nanoemulsi yang terbentuk berwarna jernih.

\subsubsection{Uji pH}

Dilakukan uji pH pada suhu $25^{\circ} \mathrm{C}$ (pada suhu ruang menggunakan menggunakan pH-meter. Dilakukan setiap minggu selama 4 minggu. Dicatat hasil $\mathrm{pH}$ meter sediaan nanoemulsi.

\subsubsection{Uji Viskositas}

Uji viskositas dilakukan dengan cara mengambil 0.5 $\mathrm{ml}$ sediaan kemudian dibaca viskositasnya menggunakan alat viscometer Brookfield DV$2 T$. Dilakukan satu kali setiap minggu selama 4 minggu. Dicatat hasil viskositasnya.

\subsubsection{Uji Organoleptis}

Uji organoleptis yang dilakukan meliputi wujud, warna, dan aroma sediaan nanoemulsi, setiap minggu selama 4 minggu

\subsubsection{Uji Sentrifugasi}

Uji sentrifugasi nanoemulsi dalam tabung sentrifugasi dimasukkan kedalam sentrifugator dengan kecepatan putaran 3800 rpm selama 30 menit. Uji sentrifugasi bertujuan untuk mengetahui kestabilan sediaan nanoemulsi dengan cara mengamati pemisahan fase setelah disentrifugasi. Uji ini diperlukan untuk mengetahui efek guncangan pada saat transport produk terhadap tampilan fisik produk.

\subsubsection{Uji Pengukuran Distribusi}

\section{Ukuran Globul}

Diambil $1 \mathrm{ml}$ sediaan nanoemulsi minyak biji labu kemudian ditambahkan aquabidestilata hingga 20-40 ml. Dan dilakukan uji ukuran globul menggunakan alat zetasizer

\subsection{Penyimpulan Hasil Penelitian}

a. Biji labu kuning dari hasil ekstraksi dengan metode soxletasi dapat menghasilkan minyak yang mengandung asam amino, Zn (seng), Mg (magnesium), Asam lemak utama (linoleat, oleat, palmitat, dan stearat), vitamin $E$ (tokoferol), dan karetenoid yang berfungsi sebagai anti aging.

b. Minyak biji labu dapat diformulasikan menjadi sediaan nanoemulsi topikal sebagai anti aging. 
Pemanfaatan Minyak Biji Labu.........Rohani, Shibghatun, Romdhonah, Lily.

c. Nanoemulsi dari minyak biji labu memiliki stabilitas yang baik dan nyaman saat digunakan.

\section{BAB 4. HASIL YANG DICAPAI}

\subsection{Hasil Uji Organoleptis}

\section{Formula 1}

\begin{tabular}{|c|c|c|c|}
\hline Minggu & Warna & Bau & Wujud \\
\hline$\overline{0}$ & Kuning jernih & Aroma minyak & Transparan \\
\hline 1 & Kuning jernih & Aroma minyak & Transparan \\
\hline 2 & Kuning jernih & Aroma minyak & Transparan \\
\hline 3 & Kuning jernih & Aroma minyak & Transparan \\
\hline 4 & Kuning jernih & Aroma minyak & Transparan \\
\hline
\end{tabular}

\section{Formula 2}

\begin{tabular}{rlll}
\hline \multicolumn{1}{l}{$\begin{array}{l}\text { Minggu } \\
\text { ke }\end{array}$} & Warna & Bau & Wujud \\
\hline $\mathbf{0}$ & Kuning jernih & Aroma minyak & Sedikit keruh \\
$\mathbf{1}$ & Kuning kehijauan & Aroma minyak & Sedikit keruh \\
$\mathbf{2}$ & Kuning kehijauan & Aroma minyak & Sedikit keruh \\
$\mathbf{3}$ & Kuning kehijauan & Aroma minyak & Sedikit keruh \\
$\mathbf{4}$ & Kuning kehijauan & Aroma minyak & Sedikit keruh \\
\hline
\end{tabular}

\section{Formula 3}

\begin{tabular}{|c|c|c|c|}
\hline \multicolumn{4}{|l|}{ ke } \\
\hline$\overline{0}$ & Kuning jernih & Aroma minyak & Sangat keruh \\
\hline 1 & Kuning kehijauan & Aroma minyak & Sangat keruh \\
\hline 2 & Kuning kehijauan & Aroma minyak & Sangat keruh \\
\hline 3 & Kuning kehijauan & Aroma minyak & Sangat keruh \\
\hline 4 & Kuning kehijauan & Aroma minyak & Sangat keruh \\
\hline $\begin{array}{l}\text { Sediaan } \\
\text { kan sedi } \\
\text { nsparan } \\
\text { uran glo }\end{array}$ & $\begin{array}{l}\text { oemulsi meru- } \\
\text { dengan sistem } \\
\text { bening dengan } \\
\text { seragam dan }\end{array}$ & $\begin{array}{l}\text { sangat } k \\
\text { Solans, } 2 \\
\text { 2009). B } \\
\text { formulasi }\end{array}$ & $\begin{array}{l}\text { (Tadros, } 20 \\
\text { Fast \& Mecc } \\
\text { sarkan hasil } \\
2 \text { dan } 3, \text { w }\end{array}$ \\
\hline
\end{tabular}


sistem nanoemulsi yang paling mendekati adalah formulasi 1 dimana, formulasi tersebut memperlihatkan wujud sediaan yang tranparan dibandingkan dengan, kedua formulasi lainnya. Dimana formulasi 2 yang memperlihatkan wujud sediaan yang sedikit keruh dan formulasi 3 yang mempelihatkan sujud sediaan yang sangat keruh. Hal ini diperkirakan terjadi karena ukuran partikel globul yang lebih besar pada formulasi 2 dan ukuran globul paling besar pada formulasi 3 dibandingkan dua formulasi lainnya. Namun hal ini dibuktikan pada uji pengkuran partikel globul. Stabilitas wujud sediaan pada ketiga formulasi sendiri cukup baik terlihat dari wujud sediaan dari ketiga formulasi yang tidak berubah pada hasil pengamatan tiap minggunya.

Minyak biji labu kuning mengandung asam lemak dengan konsentrasi yang cukup tinggi, dimana asam lemak utama yang terkandung diantaranya linoleat, oleat, palmitat, dan stearat (Hargono, 1999). Sehingga aroma yang timbul dari ketiga formulasi nanoemulsi minyak biji labu (formulasi 1, 2 dan 3) pada tiap minggunya tercium seperti aroma minyak, selain itu mengingat basis yang digunakan dalam percobaan kali ini merupakan basis larut minyak.

Berdasarkan literatur warna yang terlihat dari minyak biji labu adalah hijau terang hingga merah gelap, hal ini sesuai dengan warna ekstrak biji labu yang terbentuk dalam penelitian ini yaitu berwarna merah kecoklatan (Anonim,2014). Pada fomula 1 terlihat warna sediaan berwarna kuning jernih yang konsisten pada pengamatan tiap minggunya. Warna tersebut apabila dibandingkan dengan literatur kurang sesuai dengan warna minyak biji labu, hal ini kemungkinan dikarenakan dalam formula bukan hanya mengandung minyak saja namun juga mengandung eksipien dan diperkirakan warna kuning yang terbentuk berasal dari warna asli tween yang berwarna kuning (Rowe, 2009).

Pada formulasi 2 dan 3 terlihat warna sediaan juga berwarna kuning jernih pada hari pertama pembuatan (minggu ke-0), sedangkan pada pengamatan minggu 1,2,3,4 terlihat warna sediaan yang berwarna kuning kehijauan. Warna kuning yang terbentuk kemungkinan disebabkan oleh 
Pemanfaatan Minyak Biji Labu.........Rohani, Shibghatun, Romdhonah, Lily.

campuran minyak biji labu dngan eksipien lain dalam hal ini tween yang memiliki warna asli kuning (Rowe, 2009), sehingga terbentuk warna kuning pada formula. Pada minggu berikutnya formula terlihat sedikit kehijauan, hal ini dimungkinkan karena pengaruh dari warna asli minyak biji labu atau stabilitas dari formula ini

\subsection{Hasil Uji Viskositas}

Uji viskositas bertujuan untuk mengetahui kekentalan dari sediaan nanoemulsi dari minyak biji labu kuning.Uji viskositas dilakukan pengamatan selama 4 minggu. Berdasarkan hasil pengukuran menggunakan viscometer Brookfield DV2T, bahwa viskositas masing-masing nanoemulsi pada formula I dan II mengalami peningkatan tiap minggunya karena jumlah surfaktan yaitu tween yang digunakan lebih sedikit sehingga sediaannya lebih cair, transparan dan mudah dituang sedangkan formula III mengalami penurunan dan penaikan dan nilai viskositas lebih besar karena jumlah surfaktan yaitu tween yang digunakan lebih besar sehingga sulit dituang. Diketahui bahwa viskositas berpengaruh pada pelepasan zat aktif dari sediaan, dan nilai viskositas yang sangat besar sulit melepaskan zat aktif sehingga efek farmakologi untuk antiaging pun tidak optimal. Nilai viskositas bergantung dari surfaktan yang digunakan serta cenderung meningkat dengan adanya peningkatan viskositas. Maka formula I dan II lebih baik daripada formula III.

\section{Grafik Uji Viskositas}

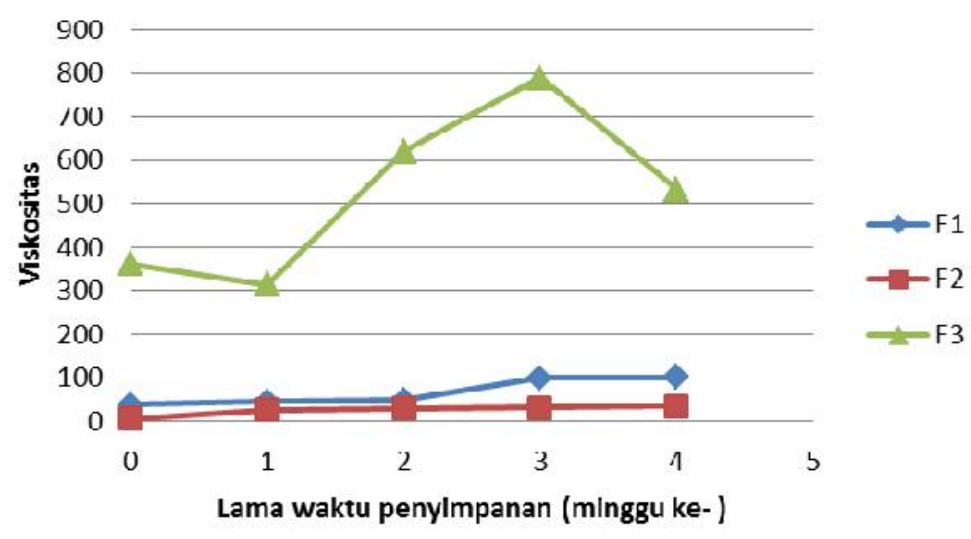


Hasil viskositas dianalisis secara statisik, berdasarkan literatur Sarwono (2009) dan S.Christianus (2010) dilakukan uji statistik One Way Anova secara asumsi bahwa dengan uji kolmogorov-smirnov hasil menunjukkan data terdistribusi normal, karena nilai $p$-value data tersebut $>a$ (0.05). Kemudian dilanjutkan dengan uji Homogenity of Variance, diketahui bahwa data tersebut memiliki variansi yang berbeda dibuktikan dengan hasil $p$-value $(0.005)<\alpha(0.05)$, selanjutnya untuk melihat rata-rata yang berbeda dibuktikan dengan uji ANOVA dan diketahui bahwa nilai $p$-value $(0.000)<\alpha(0.05)$ maka disimpulkan bahwa rata-rata formula I, formula II dan formula III berbeda secara signifikan. Perbedaan ketiga formula tersebut dapat ditunjukkan dengan uji perbandingan ganda sehingga diperoleh rata-rata fomula $3<$ rata-rata formula $2<$ rata-rata formula 3

\section{Grafik Uji pH}

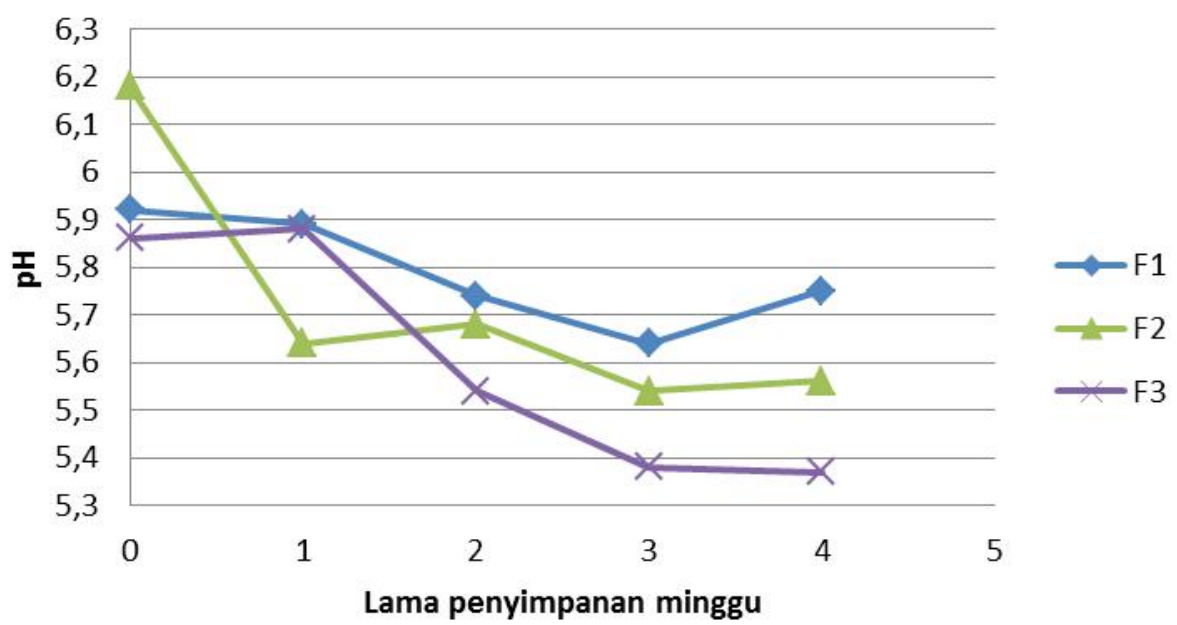

Berdasarkan hasil uji $\mathrm{pH}$ dan grafik $\mathrm{pH}$ pada ketiga formula selama penyimpanan disuhu ruangan $\left(25^{\circ} \mathrm{C}\right)$, menunjukkan nilai $\mathrm{pH}$ yang tidak jauh berbeda. Ketiga formula memiliki nilai $\mathrm{pH}$ yang berfluktuasi tiap minggunya. Akan tetapi formula I menunjukkan fluktuasi nilai $\mathrm{pH}$ yang lebih baik. Hasil Uji $\mathrm{pH}$ dari ketiga formula ini masih dinyatakan baik, $\mathrm{pH}$ yang baik bagi sediaan topikal 
Pemanfaatan Minyak Biji Labu.........Rohani, Shibghatun, Romdhonah, Lily.

untuk kulit adalah $\mathrm{pH}$ yang sama dengan $\mathrm{pH}$ kulit yaitu $4,5-6,5$. Sediaan topikal yang ideal adalah tidak mengiritasi kulit dan tidak bersifat terlalu asam dan terlalu basa untuk penerimaan penyerapan obat pada kulit. Hal ini dikarenakan bahan-bahan yang digunakan berada pada kisaran $\mathrm{pH}$ netral seperti tween 80 memilki $\mathrm{pH}$ 7, sorbitol memiliki $\mathrm{pH}$ 3.5-7 (menurut USP 32-NF27), dan aquabidestilata memiliki $\mathrm{pH} 7$. Walaupun demikian, terlihat sedikit perbedaan $\mathrm{pH}$ diantara formula tersebut.

Hasil uji pH dianalisi secara secara statistik, dilakukan uji statistik One Way Anova secara asumsi bahwa dengan uji kolmogorov-smirnov hasil menunjukkan data terdistribusi normal, karena nilai $p$-value $(0.55)$ data tersebut $>\alpha(0.05)$. Kemudian dilanjutkan dengan uji Homogenity of Variance, diketahui bahwa data tersebut memiliki variansi yang sama
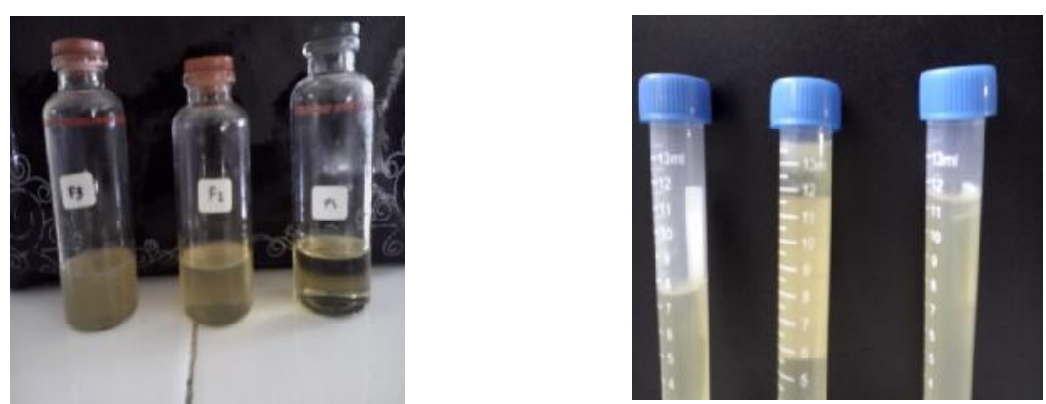

Gambar 6.Sebelum sentrifugasi Gambar 7.Hasil uji sesudah sentrifugasi

dan dibuktikan dengan hasil $p$-value (0.250) > a (0.05), selanjutnya dilanjutkan uji ANOVA dan dibuktikan pengujian tersebut memiliki nilai $p$-value $(0.443)>a(0.005)$ maka disimpulkan bahwa rata-rata formula I, formula II dan formula III sama secara signifikan.

\subsection{Hasil Uji Sentrifugasi}

Ketiga formula nanoemulsi disentrifugasi dengan kecepatan 3800 rpm selam 30 menit, dan hasilnya ada pada tabel 3. Dan Gambar 7 menunjukkan tidak terjadi pemisahan fase pada formula I dan II sehingga formula I dan III memiliki kestabilan selama 1 tahun (Rieger, M.M, 1994). Sedangkan pada formula II terjadi pemisahan, berarti formula tersebut tidak stabil secara mekanik, karena kandungan tween sebagai surfaktan dalam formula ini paling sedikit dibanding formula lainnya $22.5 \%$ sehingga kurana mampu menjaga kestabilan nanoemulsi 


\subsection{Hasil Uji Pengukuran Dis- tribusi Ukuran Globul}

Penentuan ukuran nanoemulsi ditentukan dengan menggunakan zetasizer mempunyai ukuran globul yang berkisar 5-200 $\mathrm{nm}$. Berdasarkan hasil pengukuran, minggu ke-2 diperoleh bahwa ukuran partikel masing-masing formula.Pada formula I, II, III berturut-turut yaitu $13.64 \mathrm{~nm}, 163.2$ $\mathrm{nm}$, dan $70.66 \mathrm{~nm}$. Berdasarkan nilai ukuran partikel tersebut diketahui bahwa ukuran masingmasing globul berbeda, namun ukuran tersebut masih dalam range yang diterima untuk ukuran nanopartikel. Pada umumnya penggunaan konsentrasi surfaktan dan kosurfaktan dapat menurunkan tegangan permukaan karena adanya peningkatan absorpsi surfaktan diantara minyak -air sehingga memperkecil ukuran globul dari sediaan nanoemulsi (Salim, Basri, Rahman, Abdullah, Basri \& Salleh,2011) Selain itu, kombinasi antara peningkatan konsentrasi surfaktan dan energi pengadukan cenderung menghasilkan penurunan ukuran globul (Salager, et.al., 2002).

Hasil pengukuran distribusi ukuran globul pada minggu ke-2, sediaan tidak terjadi pengadukan setelah penyimpanan, maka ukuran globul pada formula III walaupun konsentrasi tween 80 paling besar yaitu $33.75 \%$ dari formula I yaitu 30\% tetapi konsentrasi sorbitol paling kecil pada formula III sebesar $6.25 \%$ dari formula I sebesar $15 \%$ sehingga hasil ukuran globul cukup besar pada formula III dibanding formula I. Kemudian formula II memiliki konsentrasi tween dan sorbitol sama yaitu $22.5 \%$. Maka dapat disimpulkan bahwa konsentrasi surfaktan dan kosurfaktan yaitu tween 80 dan sorbitol dari masing-masing perbandingan mempengaruhi penurunan distribusi ukuran globul nanoemulsi (Piao \& Adachi,2006).

\subsection{Kemajuan Pekerjaan}

Pembuatan nanoemulsi dari minyak biji labu kuning ini dilakukan dengan mengekstraksi minyak biji terlebih dahulu kemudian di formulasi menjadi nanoemulsi dan dilakukan evalusai sediaan. Hasil pemanfaatan minyak biji labu dapat dilihat pada Gambar 8, Gambar 9 dan Gambar 10

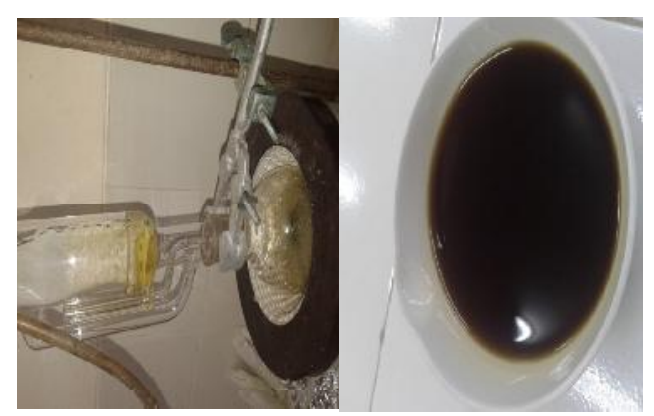

Gambar 8. Ekstraksi sokletasi minyak biji labu kuning 

Rohani, Shibghatun, Romdhonah, Lily.

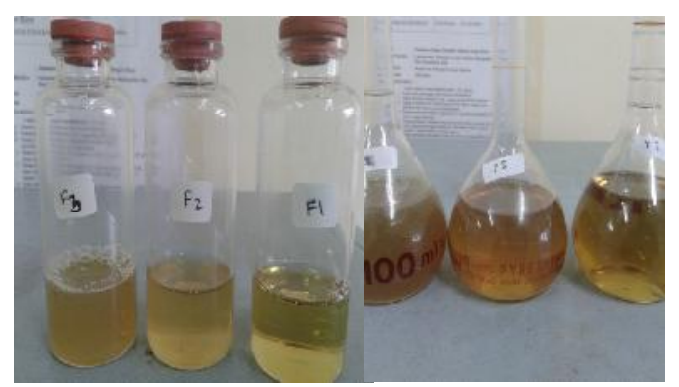

Gambar 9. Formulasi nanoemulsi minyak biji labu kuning
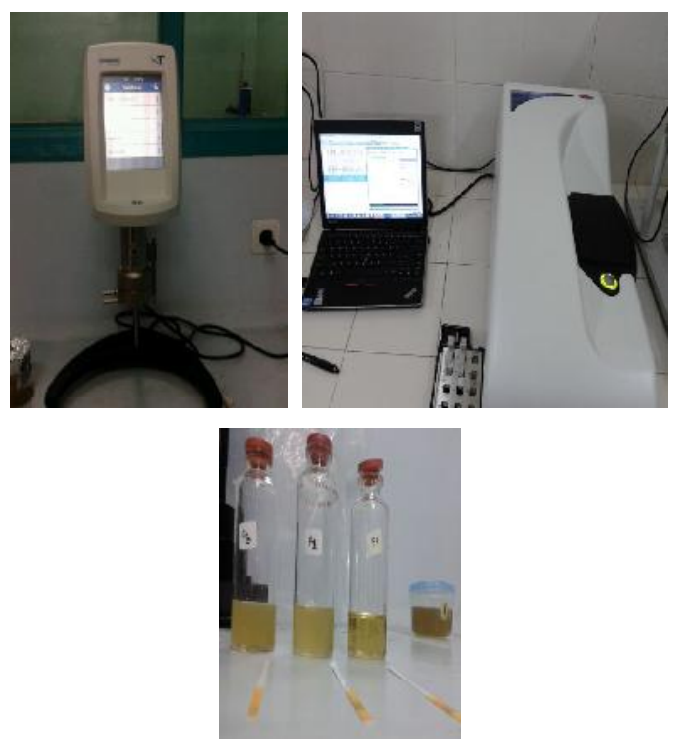

Gambar 10. Uji ukuran partikel, Uji $\mathrm{pH}$ dan Uji viskositas nanoemulsi

\subsection{Pemeriksaan secara kualitatif senyawa vitamin $E$}

Uji kualitatif dengan KLT bertujuan untuk mengetahui ada tidaknya kandungan senyawa vitamin $\mathrm{E}$ (tokoferol) yang terkandung dalam minyak biji labu kuning (Cucurbita moschataD.)standaryang digunakan adalah senyawa tokoferol. Fase diam yang digunakan adalah Silika Gel F254 dan fase gerak menggunakan $\mathrm{n}$ heksa-etil asetat (90:10) dengan pereaksi semprot adalah antimon chloride yang menunjukkan adanya perubahan warna spot tokoferol di visible adalah kuning kelabu dan menandakan adanya senyawa tokoferol. Berdasarkan migrasi atau perpindahan pada plat KLT yaitu berdasarkan nilai $\mathrm{Rf}$ diperoleh nilai Rf sebesar $0,68 \mathrm{~cm}$ yang ideal karena mendekati nilai Rf standar tokoferol yaitu $0,71 \mathrm{~cm}$. Hasil uji kualitatif kandungan senyawa vitamin E minyak biji labu kuning, dapat dilihat pada gambar berikut :

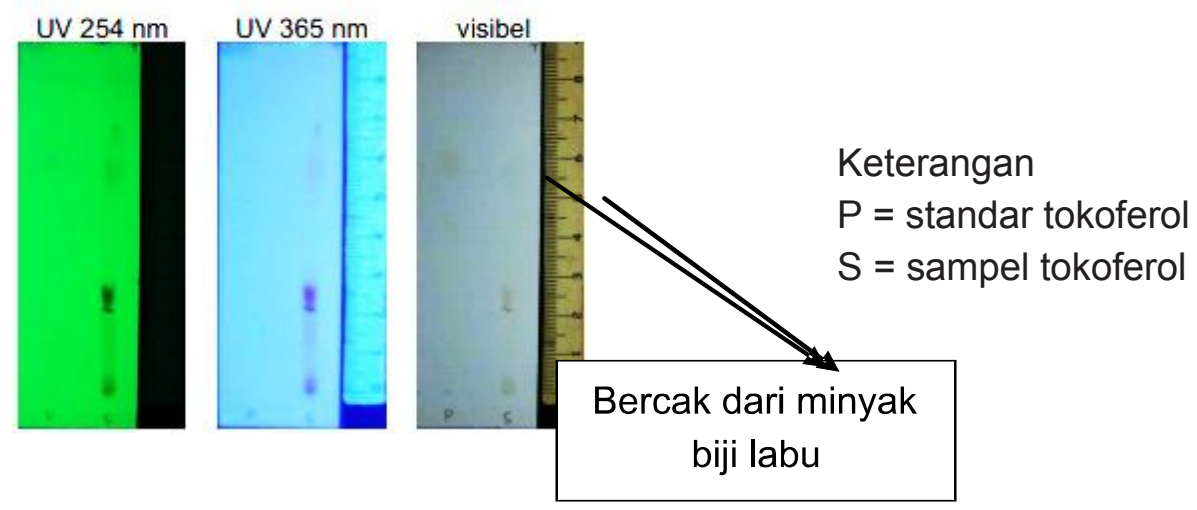


4.8 Uji Kuantitatif senyawa vitamin E dari minyak biji labu kuning (Cucurbita moschata D.)

Uji kualitatif senyawa vitamin E dilakukan dengan metode KLT densitometry bertujuan untuk mengetahui kadar dari sampel yang mengandung senyawa vitamin $E$ (tokoferol) dalam minyak biji labu kuning (Cucurbita moschata D.). Standar yang digunakan adalah senyawa tokoferol murni. Fase diam yang digunakan adalah Silika Gel $60 \mathrm{~F}_{254}$ dan fase gerak menggunakan $n$ heksa-etil asetat (90:10) dan menggunakan plat KLT pada jarak rambat $8,0 \mathrm{~cm}$. Pada awalnya dilakukan ekstraksi $2 \mathrm{ml}$ heksan dari sampel serbuk biji labu kuning, lalu divortex. Diambil fase heksan, ditambahkan pelarut etanol $2 \mathrm{ml}$ kedalam residu, divortex lagi dan disentrifuge.

Dilakukan perulangan 3 kali dan ditambahkan $100 \mu$ l etanol. kemudian spoting $20 \mu \mathrm{l}$ pada plat silikagel menggunakan microsyringe, sama halnya dengan baku standar tokoferol. Lakukan penjenuhan chamber dielusi hingga batas diangkat dan dianginkan. Kemudan dilakukan densitometry tokoferol dengan TLC scanner $\lambda$ max $278 \mathrm{~nm}$. Setelah itu ditentukan nilai resolusi yang optimal dari regresi linier standaar tokoferol yaitu 0,99 dan dibandingkan dengan sampel yang masuk range area pada standar tokoferol. Diketahui bahwa sampel positif masuk standar regresi pada range 64491,53118483,9 yaitu sebesar 71498,1 . Berikut adalah hasil analisis kadar metode TLC densitometri :

\begin{tabular}{|c|c|c|c|c|c|c|}
\hline Sampel & $\begin{array}{c}\text { Berat } \\
\text { sampel } \\
*\end{array}$ & $\begin{array}{c}\text { Spoting } \\
\text { sampel } \\
(\mu \mathrm{l})\end{array}$ & $\begin{array}{c}\text { Jumlah } \\
\text { spoting } \\
\text { sampel } \\
(\mu \mathrm{l})\end{array}$ & $\begin{array}{c}\text { Area } \\
\text { dokoferol } \\
\text { dalam } \\
\text { sampel } \\
(\mu \mathrm{l})\end{array}$ & $\begin{array}{c}\text { Kadar } \\
\text { tokoferol } \\
(\mathrm{ppm})\end{array}$ \\
\hline $\begin{array}{c}\text { Minyak Biji } \\
\text { Labu }\end{array}$ & 0,1256 & 20 & 25120 & 71498,4 & 2,41975 & 95,94 \\
\hline
\end{tabular}


Pemanfaatan Minyak Biji Labu.........Rohani, Shibghatun, Romdhonah, Lily.

\section{Hasil kurva regresi linier standar tokoferol}

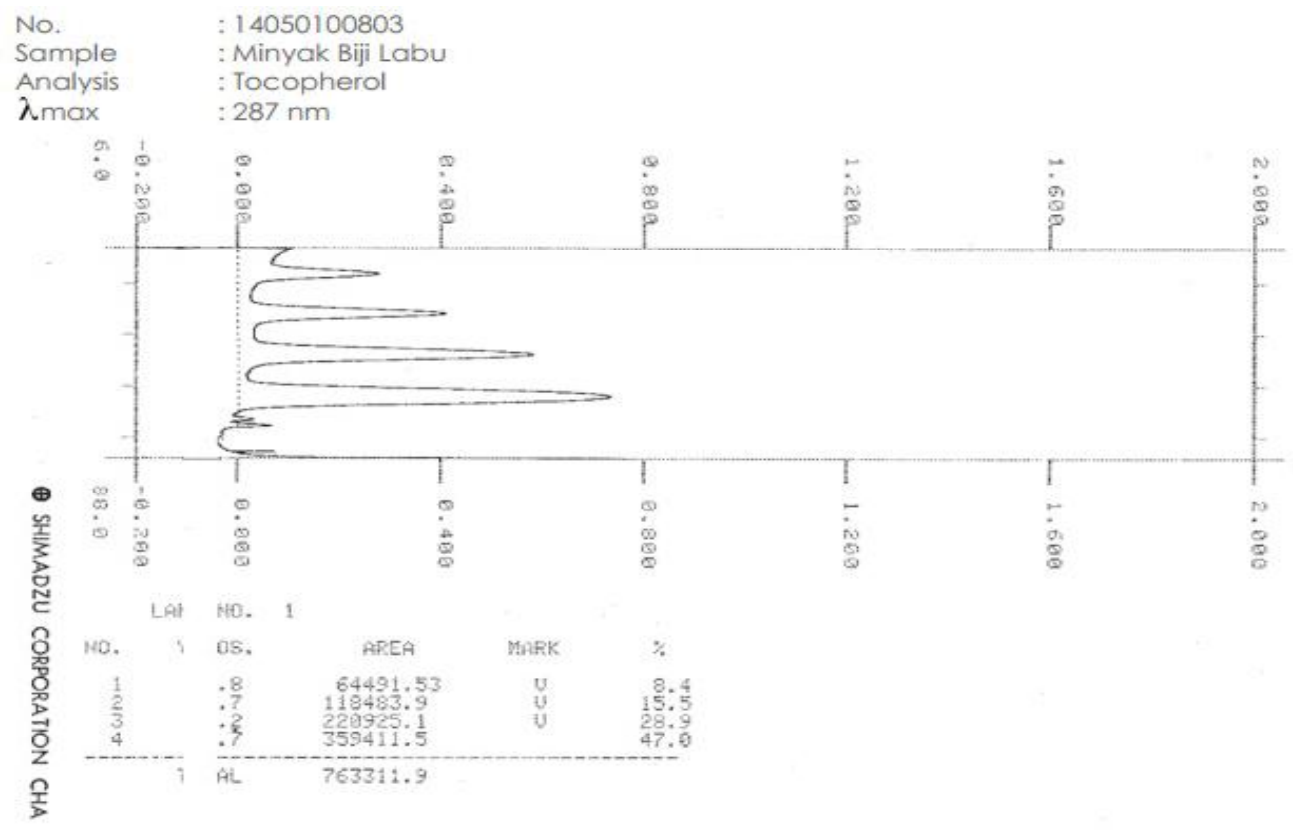

Hasil kurva regresi linier sampel minyak biji labu

Minyak Biiji labu
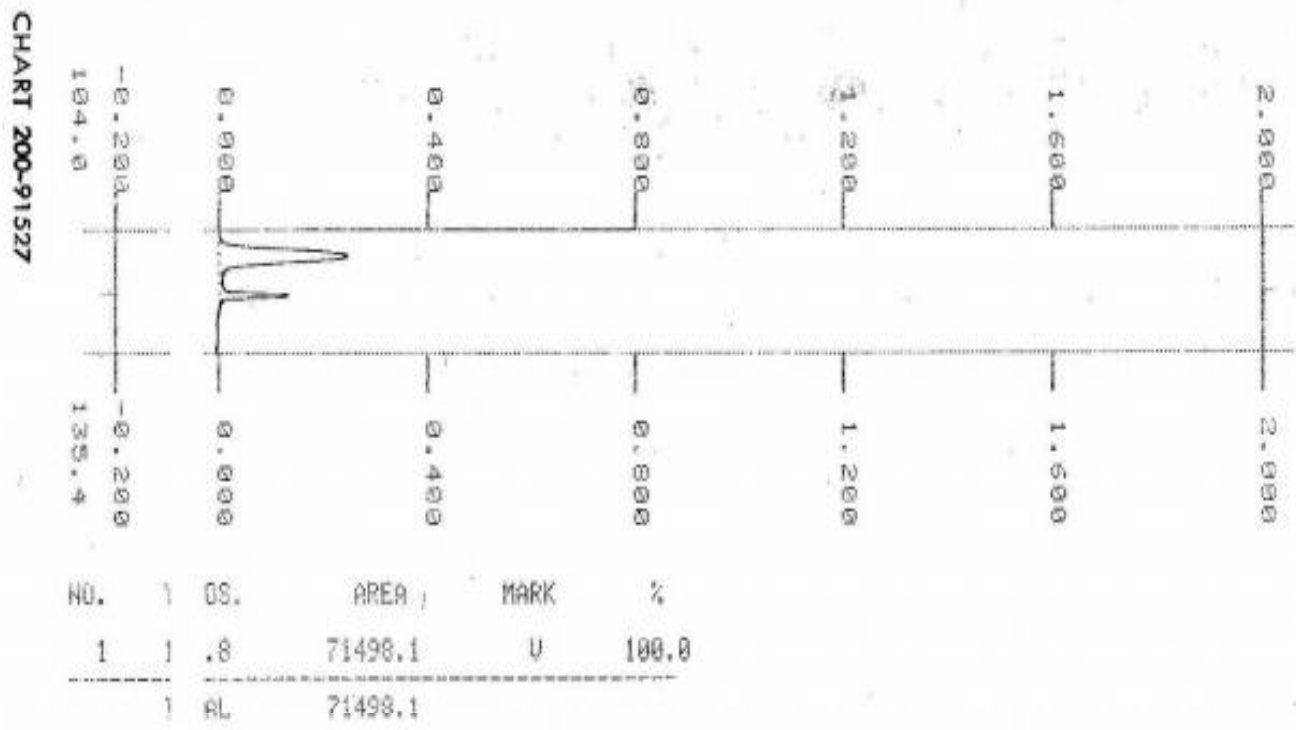
KHAZANAH, Vol. 7 No.2 Januari 2015

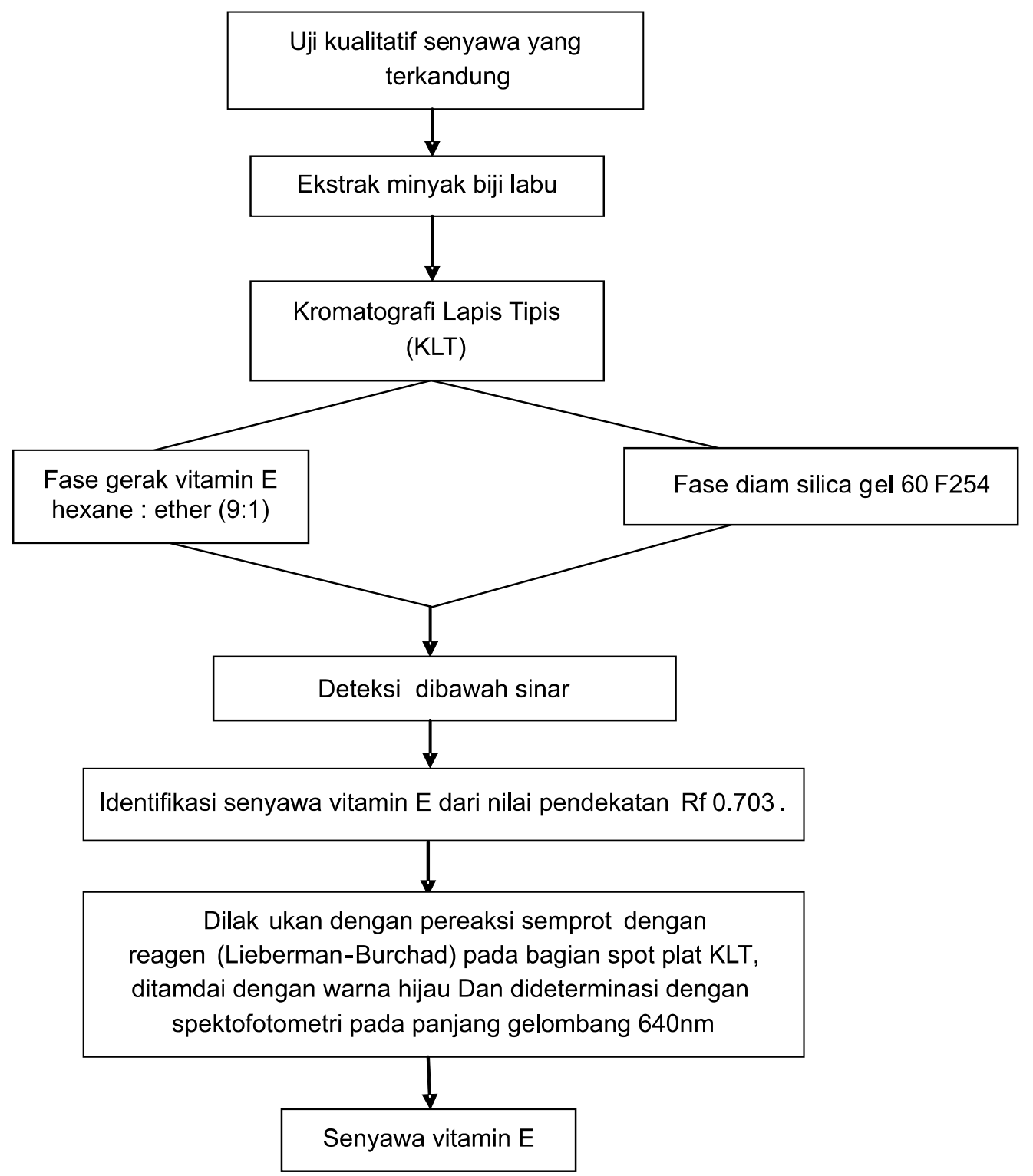

4.9 Uji determinasi biji labu kuning (Cucurbita moschata D.)

Penelitian ini menggunakan biji labu kuning (Cucurbita moschata D.) yang diperoleh dari provisi Kalimantan barat. Uji makroskopik berdasarkan pengamatan bagian biji labu kuning dan disesuaikan dengan literatur dari buku Flora of Java. Kemudian uji mikroskopik biji labu untuk identifikasi jenis biji yang digunakan. Determinasi dilakukan bertujuan untuk 
Pemanfaatan Minyak Biji Labu.........Rohani, Shibghatun, Romdhonah, Lily. memastikan kebenaran tanakebenaran tanaman dan man dan menghindari kesalamenghindari kesalahan dalam han penggunaan nya.

Penelitian ini menggunakan biji labu kuning, hasil budidaya yang diperoleh dari kota Balikpapan, Kalimantan Timur. Determinasi tanaman dilakukan bertujuan untuk memastikan penggunaanya (Backer, 1965). Hasil determinasi tanaman biji labu kuning bahwa jenis biji labu kuning yang diperoleh adalah jenis spesies Cucurbita moschata (Duch) Poir, dengan suku Cucurbitaceae

Kopada Yth.

Sdrissdr. Rohani Panjaitan

NIM. 1e61.3161

Fukultes Furmasi T:II

Di Yezyakarta

\section{Denenn liocisat,}

Bersama ini kani sampaikan lsasil identifikasaideterminasi samped yang Sucklara kinmkan ke Bagjan Biologi Farmasi. Fakuitas Farmasi UGM, adalah

\begin{tabular}{|c|c|c|}
\hline Va.Pendafraran & Jeais & Sikil \\
\hline 257 & Cucunbuer moschase ( Duch. ) Poir & Cucurtaitacese \\
\hline
\end{tabular}

Demikian, semojea dapar digumakan setagaimana mestieya.

Yorgakarta, 10 Jumi 2014

Ketua 
BAB 5. Rencana Tahapan Berikutnya

\section{Publikasi jurnal}

\section{DAFTAR PUSTAKA}

Anonim, 1995, Farmakope Indonesia, Edisi IV, DepartemenKesehatanRepublik Indonesia, Jakarta, 4, 7, 405, 515,771

Anonim, 2014, Pumpkin oil available at http://www.reference.com/ browse/green + cabbage +seed+oil , diakses pada tanggal 26 Mei 2014

Anonim, 2009, Unique E-Book of The $S$ Pharmacopoeia 30-NF25, The Unites States Pharmacopenia Convention

Backer, C.A., Brink, R. C. B. V. D., 1965, Flora Of Java (spermatophytes only), N. V. P. Noordhoff-groningen-the Netherlands, Leyden, 139

Brotodjojo, L C., 2010, Semua Serba Labu Kuning, Gramedia Pustaka Utama, Jakarta.

Fast, J. P., \& Mecozzi, S., 2009, Nanoemulsions for Intravenous Drug Delivery, In Villiers, M. M. De., Aramwit, P., \& Kwon, G. S., (Ed)., Nanotechnology in Drug Delivery, New York: American Association of Pharmaceutical Scientists, 461, 463-465, Oktober 10, 2013, http://books. google.co.id.

Hargono, Djoko., 1999, Manfaat Biji
Labu (Cucurbita sp.) Untuk Kesehatan, Media Litbangkes Volume IX Nomor 2, hal 4-5.

Hutapea, J. R., 1994, Inventaris Tanaman Obat Indonesia (III), Badan Penelitian dan Pengembangan Kesehatan, Departemen Kesehatan, Jakarta. Korting(a), H. C., Korting(b), M. S., 2010, Carriers in the Topical Treatment of Skin Disease, In korting, Monika Schafer (Ed), Drug Delivery, Berlin: SpringerVerlag Berlin Heidelberg, 446, Oktober 10, 2013, http://books. google.co.id.

Mi Young, Kim.,Eun Jin, Kim., Young-Nam, Kim., Changsun, Choi.,and Bog-Hieu, Lee., 2012, Comparison of the chemical compositions and nutritive values of various pumpkin (Cucurbitaceae) species and parts, Nutr Res Pract, 6(1): 21-27.

Piao, J.\& Adachi, S,., 2006, Stability of O/W Emulsion Prepared Using Various Monoacylsugar Alcoohols as an Emulsifier. Innovative Food Science and Emerging Technologies 7, 216

Raharjo Tri Joko, Laily Nurliana, dan Sabirin Mastjeh, 2011, Phospolipids From Pumpkin (Cucurbita moschata Duch.)Poir) Seed Kernel Oil And Their Fatty Acid Composition, Indo.J.Chem., 11(1), 48-52, 50 

Rohani, Shibghatun, Romdhonah, Lily.

Rieger M.M., 1994, Emulsi, Dalam : Lachman. L., H.A., Liberman, \& J.L. Kanig. Teori dan Praktek Farmasi Industri I. Terjemahan: Siti Suyatmi, UI Press, Jakarta, 1029

Rowe.R.C., Sheskey.P.J .,Quinn.M.E, 2009, Hand Book Of Pharmaceutical Exipients sixth edition, Pharmaceutical Press, Washington, USA 549-551

Salager, J. L., J. M. Andérez, M. I. Briceño, de Sánchez, M. P., \& and de Gouveia M. R., 2002, Emulsification Yield Related to Formulation and Composition Variables as well as Stirring Energy, Rev. Téc. Ing. Univ. Zulia. Vol. 25 (3), 16

Salim, N., Basri, M., Rahman, M. B., Abdullah, D. K., Basri, H., \& Salleh, A. B., 2011, Phase Behavior, Formation and Characterization of Pal,Based Esters Nanoemulsion Formulation containing Ibuprofen. J Nanomedic Nanotechnol Vol 2 Issue 4, 1-5

Sarwono Jonathan, 2009, Panduan LengkapUntukBelajarKomputasi Statistik Menggunakan SPSS 16 Ed.I, C.V ANDI OFFSET, Yogyakarta, 215, 319

Solans, Conxita, 2003, Nanoemulsions Formation, Properties, and Application, In Mittal, K. L., \& Shah, D. O., (Ed), Adsorption ang Aggregation of Surfactan in Solution., New York: Marcel Dekker, 472, Oktober 10, 2013, http://books.google.co.id.

Sudarto, 2000, Penanaman Buah Labu Kuning (Cucurbita) dan Manfaatnya, Bursa IImu, Yogyakarta, 281.

Swarbrick, J., 2007, Encyclopedia of Pharmaceutical Technology $\left(3^{\text {rd }}\right.$ Edition), Volume 1, New York : Informa Healtcare USA, 1561-1562

Tadros, Tharwat F., (Ed), Applied Surfactan: Surfactan in Nanoemulsion, Weinheim: Wiley-VCH Verlag, 285-286, Oktober 10, 2013, http://books. google.co.id.

Vermaak I. et al, 2011, African seed oils of commercial importance - Cosmetic application, South African Journal of Botany, No.77, 920

Wilkinson, J. B. \& Moore, R. J., 1982, Harry's Cosmeticology $7^{\text {th }}$ Edition, New York, Chemical Publishinf Company, 240-241.

Williams, J.Z., Abumrad, N. \& Barbul, A., 2002, Effect of a Specialized Amino Acid Mixture on Human Collagen Deposition Annals of Surgery, Volume 236, issue 3 , (pp. 369-375) 